\title{
7- Eski Anadolu Türkçesinin söz varlığına katkılar
}

\section{Mehmet Mustafa KARACA ${ }^{1}$}

APA: Karaca, M. M. (2021). Eski Anadolu Türkçesinin söz varlığına katkılar. RumeliDE Dil ve Edebiyat Araştırmaları Dergisi, (25), 100-109. DOI: 10.29000/rumelide.1032409.

$\ddot{\mathbf{O} z}$

Eski Anadolu Türkçesinin söz varlığını tespit için bugüne kadar yapılmış en kapsamlı çalışma şüphesiz Tarama Sözlüğü'dür. 1943-1957 yılları arasında dört cilt olarak ilk yayını yapılan Tarama Sözlüğü bu ilk hâliyle pek çok eksiği de bünyesinde barındırmıştır. 1963-1972 yılları arasında yayımlanan ikinci yayınında ise ilkine göre bazı düzeltmeler yapılmış olsa da bütün eksiklikler giderilememiştir. Bu eksikliklerin bir kısmı sözlük hazırlama teknikleriyle ilgili olup diğer bir kısmı ise Tarama Sözlüğü’nün içerdiği söz varlığının Eski Anadolu Türkçesinin söz varlığını yansıtmadaki yetersizliğidir. Son şeklini aldığı 1972 yılından günümüze kadar bazı araştırmacıların Tarama Sözlüğü’ne katkılar veya Eski Anadolu Türkçesinin söz varlığına katkılar gibi başlıklar altında yapmış oldukları çalışmalar dışında sözlüğe herhangi bir ilavede bulunulmamıştır. Bu çalışmalarla tespit edilmiş kelimeler de hâlihazırda sözlüğe dâhil edilmemiştir. Ancak tüm eksikliklerine rağmen günümüzde Türk dili çalışmaları için temel başvuru kaynağı olma özelliğini korumaktadır. Bu yazıda bazı tarihî metinlerden tespit edilen ve Tarama Sözlüğ̈̈’nde ya hiç tanıklanmamış veya madde başı olarak tanıklansa bile tarafımızdan tespit edilen anlamıyla tanıklanmamış sözcüklere yer verilerek Tarama Sözlüğü’ne katkı sağlamak amaçlanmıştır.

Anahtar kelimeler: Tarama Sözlüğü, Eski Anadolu Türkçesi, sözlükçülük, söz varlığı

\section{Contributions to the vocabulary of Ancient Anatolian Turkish}

\begin{abstract}
The most comprehensive study to date to determine the vocabulary of Old Anatolian Turkish is undoubtedly the Tarama Sözlüğü. The Tarama Sözlüğü, which was first published in four volumes between 1943-1957, also included many shortcomings in its original form. In the second publication published between 1963-1972, although some corrections were made compared to the first, not all deficiencies could be eliminated. Some of these deficiencies are related to dictionary preparation techniques, and the other part is the inadequacy of the vocabulary included in the Tarama Sözlüğu to reflect the vocabulary of Old Anatolian Turkish. Since 1972, when it took its final form, no additions have been made to the dictionary except for the studies that some researchers have done under the titles such as contributions to the Tarama Sözlüğü or contributions to the vocabulary of Old Anatolian Turkish. The words determined by these studies are not included in the dictionary at present. However, despite all its shortcomings, it is a necessity to deal with the Tarama Sözlügü, which remains the main reference source for Turkish language studies today. In this article, it is aimed to contribute to the Tarama Sözlüğü by including words that were determined from some historical texts and were either never detected in the Tarama Sözlüğü or were not identified with the meaning suggested by us, even though they are found as per item.
\end{abstract}

Dr. Ö̆̆r. Üyesi, Aydın Adnan Menderes Üniversitesi, Fen Edebiyat Fakültesi, Türk Dili ve Edebiyatı Bölümü, Eski Türk Dili ABD (Aydın, Türkiye), mmkaraca@adu.edu.tr, ORCID ID: oooo-0001-9763-3151 [Araştırma makalesi, Makale kayıt tarihi: 25.10.2021-kabul tarihi: 20.11.2021; DOI: 10.29000/rumelide.1032409]

Adres $\mid$ Address

RumeliDE Dil ve Edebiyat Araştırmaları Dergisi $\quad$ RumeliDE Journal of Language and Literature Studies

Osmanağa Mahallesi, Mürver Çiçeği Sokak, No:14/8 Osmanağa Mahallesi, Mürver Çiçeği Sokak, No:14/8

Kadıköy - ISTANBUL / TÜRKIYE 34714 Kadıköy - ISTANBUL / TURKEY 34714

e-posta: editor@rumelide.com e-mail: editor@rumelide.com,

tel: +90 505 7958124, +90 2167730616 phone: +90 505 7958124, +90 2167730616 
Keywords: Tarama Sözlüğü, Old Anatolian Turkish, lexicography, vocabulary

\title{
Giriş
}

Dillerin zenginliği söz varlıklarıyla diğer bir ifadeyle sözlüklerinin hacimleriyle ilişkilidir. Türk dili için ise ilk yazılı belgelerin ortaya çıktığı dönem olan VII ve VIII. yüzyıllardan günümüze kadar meydana getirilen eserlerin sayısı ve söz varlığı dikkate alındığında dünyanın en eski ve en zengin dillerinden biri olduğu söylenebilir. Ancak bu zenginliği tam olarak ortaya koyacak bir sözlük henüz hazırlanabilmiş değildir.

Sözlük, genel olarak "Bir dilin bütün veya belli bir çağda kullanılmış kelime ve deyimlerini alfabe sırasına göre alarak tanımlarını yapan, açıklayan, başka dillerdeki karşılıklarını veren eser, lügat” (URL-2) şeklinde tanımlanmaktadır. Sözlükler hazırlanış amacı, yöntemleri, işledikleri dil sayısı ve kavram alanları bakımından farklılık gösterirler. Çok dilli sözlükler, tek dilli sözlükler, köken bilgisi sözlükleri, terim sözlükleri, tematik sözlükler, lehçe sözlükleri, alfabetik sözlükler vb. gibi pek çok sözlük çeşidinden bahsedilebilir. Bu sözlüklerin hemen hepsinin ortak özelliği ise hazırlandı̆̆ı dile ait söz varlığını ortaya koymak ve bu söz varlığını kendi içinde veya bir başka dille karşılaştırarak açıklamaktır.

Türk dili üzerine yapılan sözlük çalışmaları denildiğinde akla gelen ilk isim Kâş̧arlı Mahmud ve XI. yüzyılda kaleme aldığı eseri Dîvânu Lugâtït-Türk'dür. Modern anlamda sözlük çalışmalarının başlangıcı olarak Şemseddin Sami’nin Kâmûs-ı Türkîsi zikredilebilir. Türk dili üzerine gerek tarihî gerekse modern anlamda hazırlanmış sözlüklerin sayısı azımsanmayacak kadar çoktur. Ancak bu sözlüklerin en kapsamlılarından biri olan Tarama Sözlüğü de dâhil olmak üzere geçmişten günümüze kadar Türk dili üzerine hazırlanan hemen hemen bütün sözlüklerin gerek yöntem gerekse bünyesinde barındırdıkları söz varlığı bakımından bazı eksikliklere sahip oldukları alanın uzmanları tarafından bilinmekte ve zaman zaman dile getirilmektedir.

\begin{abstract}
“Sözlüğün hazırlık çalışmalarına 1935 yılında başlanmıştır. İlk evrede 135 kitap taratılarak sözlüğe gereç toplanmış, bunu sözlüğ̈̈n düzenleme ve basım evresi izlemiştir. 1941 yılından başlayarak, bir yandan eldeki tarama fişleri sözlük düzeninde işlenmiş, bir yandan da kitap tarama işi sürdürülmüştür. Böylece, taranan kitap sayısı 16o'a yükselmiş ve 1943-1957 yılları arasında her biri A'dan Z'ye değin tam bir sözlük olan dört ciltlik Tanıklariyle Tarama Sözlüğü ortaya konulmuştur. Daha sonraki çalışmalarla, ilk diziyi oluşturan bu dört cildin söz varlığı bir araya getirilmiş, kimi yönlerden geliştirilmiş ve yeni taranan 67 kitabın verimleri de bunlara katılarak, 1963-1972 yılları arasında altı cilt olarak yayımlanan Tarama Sözlüğü düzenlenmiştir. Bu altı ciltten sonra da, 19741977 yılları arasında Ekler ve Dizin ciltleri yayımlanmıştır.” (Dilçin 1983: VII).
\end{abstract}

Özellikle 1943-1957 yılları arasında hazırlanan dört ciltlik Tarama Sözlüğü’nde hem sözlükçülük ilmi hem sözcüklerin doğru yansıtılmasında ve hem de taranan eser sayısı bakımından önemli eksiklikler vardır. 1963-1972 yılları arasında hazırlanan altı ciltlik Tarama Sözlüğ̈̈’nde daha önce yapılan çalışmadaki bazı yöntemsel sorunlar giderilmiş ve taranan eser sayısı 16o'tan 227'ye çıkarılmış olsa da sözlükteki bütün eksikliklerin giderildiği ve sözlüğün tam olarak ihtiyacı karşıladığı söylenemez. Tarama Sözlüğ̈̈’nün sözlükçülük ilmi bakımından yöntemsel sorunları bir yana söz varlığına kaynaklık eden/edecek pek çok tarihî metin ya incelenmemiş veya incelenmiş olsa bile söz varlı̆̆ı henüz Tarama Sözlüğü’ne ilave edilmemiştir. Ayrıca Tarama Sözlüğü için taranan eserlerin çoğunluğunun XV ve XVI. yüzyllara ait olması, Türk dilinin bu dönemden önce ve sonraki yüzyıllara ait metinlerinin yeterince taranmamış olması başka bir eksiklik teşkil etmektedir. (Akyıldız Ay 2017: 6). Bununla birlikte taranan eserlerin çok dikkatli tarandığı da söylenemez. Örneğin Dehri Dilçin Bey tarafından Tarama Sözlüğ̈̈ için taranan Süheyl ü Nev-bahâr'dan tespit edilen satula-, aşla-, binerlik gibi kelimeler sözlükte tanıklanmamıştır.

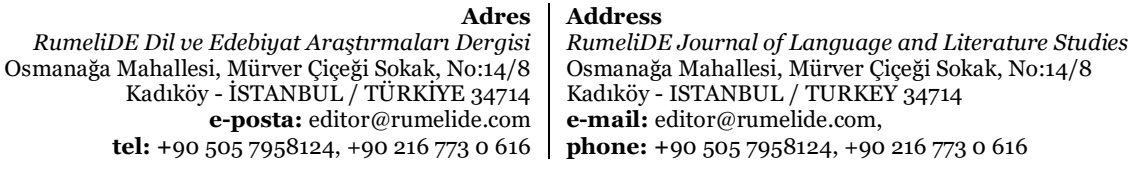


Tarama Sözlüğ̈̈’ne yöneltilebilecek diğer bir eleştiri ise taranan eser sayısının yeterli olup olmadığıdır. Şüphesiz daha fazla eserin taranması gerekmektedir. Hatta taranan eserlerin -var ise- farklı nüshalarının da taranması gerektiğini düşünmekteyiz. Her eser -aynı eserin farklı nüshaları olsa bilekendi içerisinde değerlidir ve kendine mahsus bazı zenginlikler barındırır. Zira müstensihlerin eğitim durumları, yabancı dil bilgileri, sosyal çevreleri, eserlerin hedef kitlesi gibi faktörler o eserin söz varlığını etkilemekte ve şekillendirmektedir. Örneğin Tarama Sözlüğü için Kilisli Rifat Bilge tarafindan Fatih Kitaplığı 2576 numarada kayıtlı nüshası taranan Mirsadü’-İbad adlı eserin Süleymaniye Kütüphanesi, Hacı Mahmut Efendi Kitaplığı 2235 ve İBB Atatürk Kitaplığı OE Yz 0004 numaralı nüshaları üzerinde tarafımızdan yapılan taramada hem madde başı olarak hem de bazı anlamları bakımından Fatih Kitaplı̆̆ı 2576 numaralı nüshadan tanıklanmamış sözcüklere rastlanılmıştır. Dolayısıyla Tarama Sözlüğü için taranacak eser sayısının artırılmasının yanında taranmış eserlerin taranmamış nüshaları da mümkünse taranmalıdır.

Hazırlanışından sonra yapılan metin neşri çalışmaları gösteriyor ki Tarama Sözlüğü Eski Anadolu Türkçesinin söz varlığını yansıtmak bakımından eksik kalmaktadır. Yapılan çalışmalarda karşılaşılan yeni kelime veya anlamlar zaman zaman araştırmacılar tarafından Tarama Sözlüğü’ne katkılar veya Eski Anadolu Türkçesinin söz varlığına katkılar² başlıkları altında ortaya konsa da bu eksikliğin giderilmesi için daha kapsamlı çalışmaların yapılması gerekmektedir.

"Eski Anadolu Türkçesi söz varlığına ait yeni verilerin ortaya çıkması, bu verilerle ilgili yayınlar, daha önce taranmış eserlerde kimi sözcüklerin tarayıcıların gözünden kaçmış olması ve sözlüğe yönelik kimi bilimsel eleştirilerin varlığı gibi nedenler Tarama Sözlüğü’nün yeni ve güncellenmiş bir baskısını zorunlu kılmaktadır." (Yilmaz ve Demir 2009: 496).

Benzer şekilde Tietze, "Şimdiye kadar ihmal edilen veya yeni keşfedilen kaynakların taranması ve böylece elde edilen malzemenin sözlüğe ilave edilmesi yahut bir ek cilt olarak esere katılması her okuyucunun umduğu ve beklediği şeydir." (Tietze 1993: 268) ifadeleriyle söz konusu eksikliği dile getirmektedir. Ancak bazı eksikliklerine rağmen Tarama Sözlüğ̈̈ özellikle metin neşri yapan araştırmacılara büyük kolaylıklar sağlamakla beraber hâlihazırda temel başvuru kaynaklarından biri olma özelliğini korumaktadır (Yavuz ve Küçükballı 2017: 357).

\section{Inceleme}

Bu çalışmada Behcetü'l-Hadâyık, Mirsâdüll-İbâd, Hacı Mahmud Efendi Kitaplığı Nüshası, 2235 ve , İBB Atatürk Kitaplığı OE Yz 0004, Mütercimi Meçhul Bir Acayibü'l-Mahlukat ve Garayibü'l-Mevcüdat Tercümesi, Nazmü'l-Ferâid, Acâibü'l-Mahlûkât Tercümesi, Süheyl ü Nev-bahâr ve Kıssa-i Yûsuf adlı eserlerden tespit edilen ve Tarama Sözlüğü’nde hiç tanıklanmamış veya tanıklansa bile tarafımızdan önerilen anlamıyla tanıklanmamış sözcüklere yer verilmiştir. Bu çalısmada Süheyl ü Nev-bahâr'dan yapılan tespitleri tanıklamak amacıyla alınan örnek beyitler ve kelimeler için Cem Dilçin'in (1991) okumaları (farklı olarak / ̃̃ için /y/ kullanılmıştır) ve anlamlandırmaları esas alınmıştır. Diğer kelimeler için yapılan anlamlandırmalarda ise ya örneği tespit ettiğimiz metnin neşrini yapan araştırmacının verdiği anlamlar veya Türk Dil Kurumu'nun sözlükleri (Güncel Türkçe Sözlük, Tarama Sözlüğü, Derleme Sözlüğ̈̈) esas alınmıştır. Ancak bazı kelimeler için metnin bağlamından hareketle tarafımızdan da yapılan anlamlandırmalar bulunmaktadır. Tarama Sözlüğ̈̈’ne katkı sağlayacağı düşünülen kelimeler şunlardır:

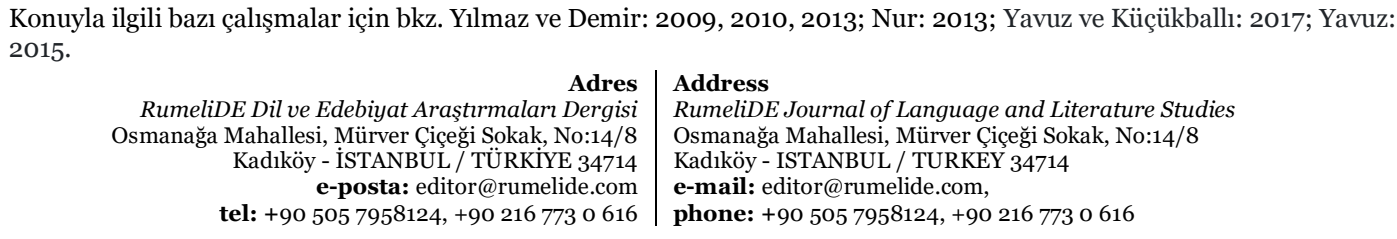


al: Düğ̈̈nde güveyin boynuna atılan mendil büyüklüğünde kırmızı bez.

Șunarsam elüm söyler isem dilüm

Ṭutarsam alum țanışursam bilüm (Dilçin 1991: 493-585).

DLT'de al "turunç renginde bir kumaş" (Ercilasun ve Akkoyunlu 2014: 541) biçimde geçen kelimeye EDTP ve TETL ve TS'de rastlanılmamıştır. DS'de Isparta ağızlarında al "1. Dügü̈nde güveyin boynuna atılan mendil büyüklüğünde kırmızı bez. 2. Kadınların alınlarına bağladıkları, yeşilli kırmızılı ipek örtü.”; Isparta, Burdur ve Zonguldak ağızlarında "Gelinlerin başına örtülen uzun, kırmızı örtü, duvak.” anlamlarıyla tanıklanmıştır. SN'den tanıklanan "Düğünde güveyin boynuna atılan mendil büyüklüğünde kırmızı bez." anlamı DLT ve DS desteklemektedir.

alın: Ön, karşı, huzur.

Mahabbet tācını başumuza urdı ve cümle melāikeyi cem` idüp taḩtumuz alında sücūd buyurdı (HM $18 \mathrm{~b} / 15)$.

Clauson, EDPT'de al maddesini açıklarken alın kelimesi için “ön” anlamını vermektedir (Clauson 1972: 121). TS'de tanıklanmayan ve Güncel Türkçe Sözlükte “ön” anlamıyla yer almayan bu kelime DS'de, Eskişehir, Kastamonu, Niğde, Afyon ve Kars ağızlarında "karşı, karşı taraf, ön” anlamlarıyla tanıklanmıştır. Kelimenin HM'den tanıklanan alın “ön, karşı, huzur” anlamlarını hem EDPT hem de DS desteklemektedir.

aşla-: Bir ağacın dalı veya gövdesi üzerine, aynı familyanın daha iyi bir türünden alınan dal, göz, tomurcuk vb. parçaları kaynaştırma işi, aşılamak.

Birez sehlrek țutmaġa başladı

Velī ol budah țutdı kim aşladı (Dilçin 1991: 217-587).

DLT ve EDPT'de tespit edilemeyen ve TS'de de tanıklanmamış fiil için Tietze, aşıla-/aşla- (< aş+1-la-) "ilave edilmek" anlamını vermiştir. (Tietze 2018: 466-467). DS'de Trabzon, Artvin ve Niğde ağızlarında "aşılamak" anlamıyla tanıklanmıştır. SN'den ve KY'den tanıklanan anlamı DS ve TETL desteklemektedir.

ayıḳlıḳ: Ayık olma durumu, sarhoşluktan kurtulma.

Ol şarābuy zevḳini girü bulup yüzlerin hergiz ayıkhgia döndermemişlerdür (İBB 101b/15-16).

TS'de ayıklık kelimesinin kökü olan ay- "ayılmak" fiili tanıklanmış ancak türemiş şekli olan ayıklı "ayık olma durumu, sarhoşluktan kurtulma” biçimi tanıklanmamıştır. Clauson, kelimeyi *ad- fiiline dayandırıp "ayık olmak" anlamını vermektedir (Clauson 1972: 45-46). Benzer şekilde adıg kelimesi DLT'de "sarhoşluktan ayılmış, aylk" anlamıyla kaydedilmiştir (Ercilasun ve Akkoyunlu 2014: 541). Clauson'un görüşünden hareketle kelimenin varsayımsal bir *ad-fiilinden türemiş olduğu kuvvetle muhtemeldir. TS'de ve DS'de tanıklanmayan ve İBB'den tespit edilen ayıklık "ayık olma durumu, sarhoşluktan kurtulma” biçimini hem Kâşgarlı’nın hem de Clauson'un vermiş olduğu anlamlar desteklemektedir.

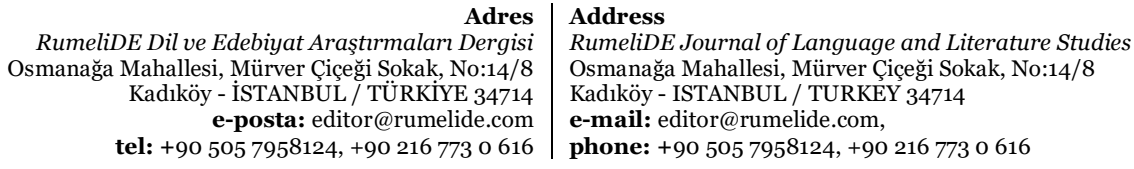


ayruca: Başka, farkll.

Ol ki ekinden ve bāğgan ve mülkden nesne hạașıl oldı ve niṣāb tamām oldı zekātın çıkara hıırmendeyiken ve anı ayruca bir eve koya (HM 244a/9).

DLT'de ayru "değilse, başka”, ad drı "iki ayrı parçası bulunan şey, çatal değnek, iki dalı olan” (Ercilasun ve Akkoyunlu 2014: 567-541) anlamlarıyla tanıklanan sözcüğü Clauson aḍdr- fiiline dayandırmakta ve "bölünmüş, ayrılmış, farklı" anlamlarını vermektedir (Clauson 1972: 63) Eski Türkçeden beri kullanılan adrı / ayrı / ayru kelimesi "başka, değilse" gibi temel anlamlarının yanında pek çok anlama gelmektedir. TS'de tanıklanmayan bu kelimenin HM'deki ayruca (<ayır-u+ca) "başka, farklı" şekli için Kâşgarlı ve Clauson'un aḍrı / ayrı / ayru için vermiş oldukları bilgiler desteklenmektedir.

bey: Tende olan leke.

Ki ayurayidi ḳayanun enin

Ḳapayidi Hindū yüzinden beyi (Dilçin 1991: 348-591).

DLT'de mey “yüzdeki ben” (Ercilasun ve Akkoyunlu 2014: 763) şeklinde yer alan kelime benzer şekilde

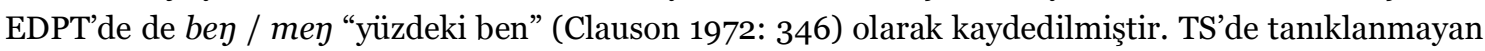
kelime DS'de Diyarbakır ağızlarında "ben, tendeki koyu renkli leke veya kabartı" ve Güncel Türkçe Sözlük'te "çoğu doğuştan, tende bulunan ufak, koyu renkli leke veya kabartı" anlamlarıyla yer almaktadır. Eski Türkçeden beri Türkçede var olduğu anlaşılan bu kelimenin SN'den tanıklanan "tende olan leke" anlamını zikredilen kaynaklar desteklemektedir.

bilezük: Bilezik.

Bilezükden üşenür iken ḳolı

Nite balta șalmaġa vardı eli (Dilçin 1991: 328-592).

DLT'de bilezük ve bilezüklen- "bilzek" olarak yer alan kelimeyi Clauson, EDPT'de bilezük "bilezik" (Clauson 1972: 63) şeklinde kaydetmiştir. TS'de tanıklanmamış kelimenin DS'de Diyarbakır ağızlarında bilezüg / bilezik "bilezik", Afyon ağızlarında bilezik "demir çember" şeklindeki kullanımları tanıklanmıştır. DLT, EDPT ve DS'deki kullanımlar SN'den tanıklanan "bilezik" anlamını desteklemektedir.

biyerlik: Binmeye yarar (at).

Binerlik semiz yunt binden öküş

Uçarda ne kim eti yinürse ḳuş (Dilçin 1991: 337-593).

DLT'de bijerlik şeklinde tespit edilemeyen kelimenin kökü olan mün- "binmek" ve türemişs şekilleri olan münül- "binilmek", müyeş- "birlikte binmek" (Ercilasun ve Akkoyunlu 2014: 766) varyantları yer almaktadır. EDPT'de bin- / min- / mün- “(at) binmek veya sürmek” (Clauson 1972: 348) anlamıyla tespit edilmiştir. TS ve DS'de tanıklanamayan kelimenin SN'den tespit edilen binerlik (< bin-er+lik ) “binilecek at" kullanımını DLT ve EDPT'deki bilgiler desteklemektedir.

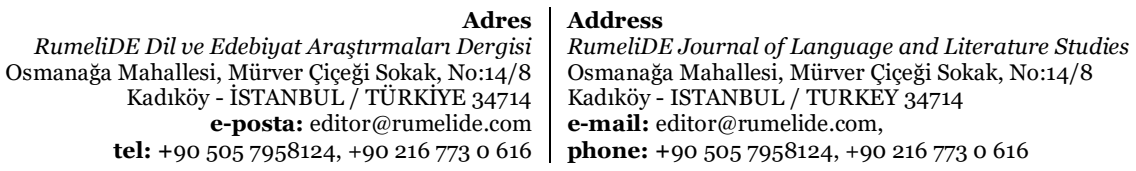




\section{boncuk (boncug்): Boncuk.}

Güher șanma boncug ola serserī

Bu sözüy bilür ḳadrini cevherī (Dilçin 1991: 465-594).

DLT'de monçuk olarak ve "süs eşyasındaki boncuk, atın boynuna takılan inci boncuk, aslan tırnağı ve muskalar" (Ercilasun ve Akkoyunlu 2014: 765) anlamlarında yer alan kelime için Clauson, bonçuk (? bonçok) maddesinde "boncuk, boncuk kolye" (Clauson 1972: 349) anlamlarını vermiştir. TS'de tanıklanmamış kelimenin SN'de tespit edilen "boncuk" anlamını hem DLT hem de EDPT doğrulamaktadır.

çiskin: Çisinti, (yağmur) çiselemek.

Vābil o yağmur ki iri çiskin ne țall

Cemd ü celed țon buz erise di dāb (Çelik 2008: 134).

NF'de çiskin “çisinti, (yağmur) çiselemek” anlamıyla görülen kelime TS'de tanıklanmamıştır. DS'de Çanakkale, İstanbul, Giresun, Artvin, Ağrı ve Adana ağızlarında çiskin (<çis+kin) "sisli ve yağmurlu hava" anlamıyla tanıklanmıştır. NF'den tanıklanan "çisinti, (yağmur) çiselemek" anlamı DS'deki anlam desteklemektedir.

düşelge: Nasip, hisse, pay.

Șıb boyamaḳ ne düşelge nașīb ü sehm dahi

Kifl ü ḥıșse vü ḳısț ü urża vü ḥaẓz ü ḳısm ü ḩalāḳ (Çelik 2008: 85-135).

NF'de düşelge "nasip, hisse, pay" (Çelik 2008: 135) anlamıla tanıklanan kelime TS'de tanıklanmamıştır. Kelime, düşelge şekliyle Tokat, Bayburt, Kars, Hatay, Kayseri, Osmaniye, Adana ağızlarında “1. Pay, miras payı. 2. Ödev” anlamlarıyla DS'de tanıklanmıştır. Ayrıca düşerge biçimiyle de Erzurum, Diyarbakır, Malatya, Gaziantep, Kayseri, Niğde ağızlarında "pay, miras payı" anlamlarıyla DS'de yer almaktadır. Başka bir kaynaktan tanıklanamayan bu kelimenin NF'den tanıklanan düşelge "hisse, pay" anlamını DS'de yer alan anlamlar desteklemektedir.

\section{itürü: Sert.}

Ṣofra üzre kendü nașībini ișār eyleye ve kimsenüy nașibine itirü baḳmaya ve țama ḳılmaya (İBB 123b/6).

Kelimenin sert sert anlamına gelen itürü itürü şekli TS'de bir kez tanıklanmıştır. Ancak tek başına itürü kullanımı tanıklanmamıştır. Hem TS'de hem de DS'de tanıklanmamış bu kelimenin İBB'den tespit edilen "sert" anlamını TS'de tanıklanan ve ikileme şekli olan itürü itürü "sert sert" kullanımı desteklemektedir.

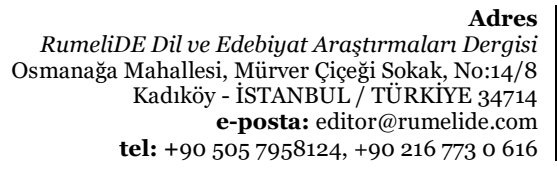

RumeliDE Dil ve Edebiyat Araştırmaları Dergisi

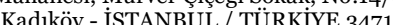
tel: +90 505 7958124, +902167730616
Address

RumeliDE Journal of Language and Literature Studies

Osmanağa Mahallesi, Mürver Çiçeği Sokak, No:14/8

Kadıköy - ISTANBUL / TURKEY 34714

e-mail: editor@rumelide.com,

phone: +90 5057958124 , +90 2167730616 
mezelen-: Alay etmek, alaya almak.

Rivāyet olınur ki Süleymān 'aleyhi's-selām șu içdükde ḩıdmetinde olan şeyāținn agiızlarını egüp mezelenürler idi (Çelik 2019: 191).

Bu gemide olanlar buya inkār idüp mezelenürler idi (Karaca 2021: 115).

TS'de mezeye almak, meze eylemek "alay etmek, eğlenmek" şekilleri tanıklanan sözcüğün mezelen- şekli TS'de geçmemektedir. TETL'de mezele- "alay etmek." DS'de mezele- "eğlenmek, alay etmek" şekliyle Çorum ağızlarında tanıklanmıştır. RAM'dan mezelen- "alay etmek" (Çelik 2019: 191) ve MAM'dan mezelen- "alaya almak, biriyle eğlenmek" (Karaca 2021: 396) olarak tanıklanan anlamı DS desteklemektedir.

oraḳ: Yarım çember biçiminde yassı, ensiz ve keskin metal bir bıçakla, buna bağlı bir saptan oluşan ekin, ot vb. biçme aracı.

Birimüz hemān bir keskin orag̉la dibinden kesdi (Çelik 2019: 214).

Kelime için ilk olarak Caferoğlu, orġak "orak" (Caferoğlu 2015: 142) anlamını vermektedir. DLT'de orgak "orak" (Ercilasun ve Akkoyunlu 2014: 777) olarak yer alan kelimeyi Clauson, EDPT'de hem orğak hem de orağ/orak olarak kaydetmiş ve or- filine dayandırarak "orak, hasat kancası" anlamını vermiştir (Clauson 1972: 216). TS'de orak/orğak olarak tanıklanmayan kelime muhtemelen orğak kelimesinin metatetik (göçüşmeli) şekli olan oğrak olarak bir eserde tanıklanmıştır. Ayrıca kelime DS'de "yarım çember biçiminde yassı, ensiz ve keskin metal bir bıçakla, buna bağlı bir saptan oluşan ekin, ot vb. biçme aracı" anlamıyla tanıklanmamıştır. Hem Kâşgarlı’nın hem de Clauson'un kelimeye vermiş olduğu anlamlar ile RAM'da "Birimüz hemān bir keskin oraġla dibinden kesdi." (Çelik 2019: 214) ifadesindeki anlam olarak birbiriyle örtüşmektedir.

oyuncaḳ (oyuncag்): Oyuncak.

Ümīżüm bu makșūdum ancag̀dur

Kalan ālem işi oyuncaġdur (Dilçin 1991: 575-630).

DLT ve EDPT'de oyuncak biçimine rastlanılmayan kelime için TETL'de oyuncak (oyun + - cak küçültme eki) "Çocukların oynamaları için yapılmış nesne." (Tietze 2018: 192) anlamı verilmiştir. TS'de tanıklanmayan bu kelime GTS'de oyuncak "oyun aracı" anlamıyla yaşamakta ve SN'deki anlamı desteklemektedir.

șadula- (șatula-): Sözü uzatmak, uzun uzun anlatmak, gevezelik etmek.

Kamusın șaduladı bir bir aya

Çü işitdi vü ol [ki] ḳaldı țana (Dilçin 1991: 453-632).

EDPT'de satula- (<*satu:) "değersiz konuşmak, gevezelik etmek" (Clauson 1972: 801) şeklinde geçen kelime benzer şekilde DLT'de de satula- "faydasız söz söylemek" (Ercilasun ve Akkoyunlu 2014: 809) biçiminde yer almaktadır. TS'de tanıklanmayan kelimenin SN'den tanıklanan anlamını EPDT ve DLT

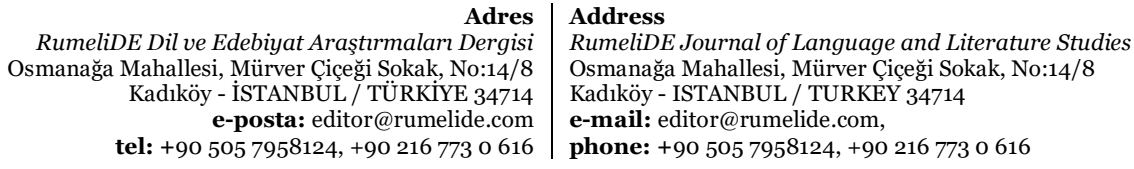


desteklemektedir. Ayrıca BH'nin karışık dilli Orhan nüshasında fiil șadula- şeklinde bir kez geçmiştir (Doğan 2019: 326).

uçmaḳlıḳ: Cennetlik.

Bu țāyife uçmaklık oldug̉ından baya ne așșı ve țamulıḳ olduġından ne ziyān? (İBB 179a/9).

Eski Türkçe'den beri “cennet” anlamına gelen uçmak kelimesi DLT'de uçmak (Ercilasun ve Akkoyunlu 2014: 915), EDPT'de ise uçmak/uştmax şeklinde geçmektedir (Clauson 1972: 257). TS'de uçmak (uçmağ, uçmah) "cennet" olarak tanıklanan kelimenin "cennetlik" anlamına gelen uçmaklık şekli tanıklanmamıştır. Günümüz Türkiye Türkçesi ağızlarında da hem uçmak hem de uçmaklkk şekilleri tanıklanamayan kelimenin İBB'den tespit edilen uçmaklık (<uçmak+llk) "cennetlik" şekli uçmak kelimesinden isimden isim yapım eki +lIk ile türetilmiş hâlidir.

uluy: Okun sapı.

Çeker terkeşinden seḥer yil bigi

Uluyı ḳayın u țavşancıl yüni (Dilçin 1991: 390-643).

Kelime, DLT'de ulun "okun gövdesi" (Ercilasun ve Akkoyunlu 2014: 915), EDPT'de ulun "ince kök, sürgün, ok şaftı” (Clauson 1972: 147) biçiminde geçmektedir. TS'de tanıklanmayan bu kelime için SN'den tanıklanan uluy "okun sapı" anlamlarını DLT ve EDTP'de kaydedilen anlamlar desteklemektedir.

yoḳla-: Araştırmak, kontrol etmek, sormak.

Bu hāalde iken bir gün Mūsā 'aleyhi's-selām ol kişiyi yoḳladı, dāyim ṣorardı hīç anı bulımazdı ḩaberin bilmezdi ki ne oldı ana (İBB 212a/13).

Yanlarında yoḳladılar gördiler bir miḳdār azıḷ buldılar șudan ve ekmekden ki bir nice müddet kendülere kifāyet ider (Karaca 2021: 73).

TS'de tanıklanamayan yoḳla- fiili için Clauson, EDPT'de "araştırmak" anlamını vermekte ve "bir şeyi not etme, araştırma” anlamındaki yok köküne dayandırmaktadır. Clauson, yok kökünden iki ayrı anlamın geliştiğini söylemekte ve birincisi için "yok etmek" ikincisi için "araştırma, hatırlama" anlamını vermektedir (Clauson 1972: 902). Yokla- fiilinin İBB'den ve MAM'dan tanıklanan "aramak, araştırmak, kontrol etmek" (Karaca 2021: 532) anlamları, Clauson'un yokla- fiili için vermiş olduğu bilgiler ile örtüşmektedir. Ayrıca kelimenin yardımcı birleşik fiille kullanımı olan yoklayu gel- "kontrol etmek; bakmak, aramak" şekli de MAM'da yer almaktadır (Karaca 2021: 532).

\section{Sonuç}

Bu çalışmada yedi farklı yazma eserden tespit edilen ve Tarama Sözlüğü’nde yer almayan on dokuz

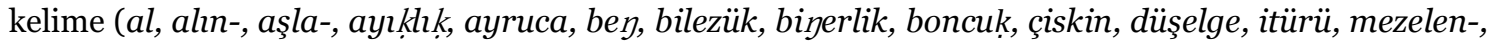
orak, oyuncak, șadula-, uçmaḳlı, uluy, yoḳla-) ele alınmıştır. Araştırmalar gösteriyor ki Tarama Sözlüğü’nün hem yöntemsel hem de söz varlığına dair eksiklikleri bir problem olarak varlığını devam ettirmektedir. Ancak tüm eksiklerine rağmen Tarama Sözlüğü, Türkoloji araştırmaları için temel

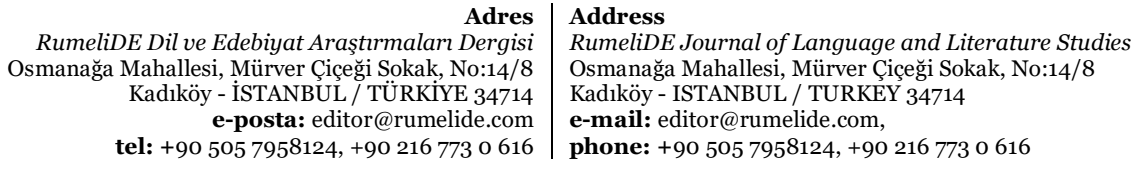


başvuru kaynaklarından biri olma özelliğini korumaktadır. Bu ihtiyacı karşılayabilcek başka bir kaynak da henüz mevcut değildir (Tietze ve Tekin 1989: 286). Söz konusu eksikliklerin giderilmesi maksadıyla yeni eserlerle birlikte taranmış eserlerin varsa farklı nüshalarının taranması ve araştırmacıların Tarama Sözlüğü’ne veya Eski Anadolu Türkçesinin söz varlığına katkılar gibi başlıklar altından yapmış oldukları tespitler sözlüğe ilâve edilmelidir. Böylelikle Türkoloji çalışmalarının temel başvuru kaynaklarından biri olan Tarama Sözlüğü daha işlevsel ve zengin hâle getirilmiş olacaktır.

\section{Kisaltmalar}

BH: Behcetü'l-Hadâyı

DS: Türk Dil Kurumu Derleme Sözlüğü

DLT: Dîvânu Lugâti't-Türk

EDPT: An Etymological Dictionary of Pre-Thirteenth Century Turkish.

GTS: Türk Dil Kurumu Güncel Türkçe Sözlük

HM: Mirsâdü'l-İbâd, Hacı Mahmud Efendi Kitaplı̆̆ı 2235 numaralı nüsha.

İBB: Mirsâdü'l-İbâd, İstanbul Büyükşehir Belediyesi Atatürk Kitaplığı OE Yz 0004 numaralı nüsha.

KY: Kıssa-i Yûsuf, Uppsala Üniversitesi Kütüphanesi O. BJ. 22 numaralı nüsha.

MAM: Mütercimi Meçhul Bir Acayibü'l-Mahlukat ve Garayibü'l-Mevcüdat Tercümesi.

NF: Nazmü'l-Ferâid

RAM: Acâibü'l-Mahlûkât Tercümesi

SN: Süheyl ü Nev-bahâr

TETL: Tarihî ve Etimolojik Türkiye Türkçesi Sözlüğü

TS: Türk Dil Kurumu Tarama Sözlüğ̈̈

\section{Kaynakça}

Akyldız Ay, D. (2017). Tarama Sözlüğü: Sözlükbilimi İlkeleri Çerçevesinde Betimsel ve Eleştirel Bir Değerlendirme. İstanbul Üniversitesi Edebiyat Fakültesi Türk Dili ve Edebiyatı Dergisi, 56 (56), 1-22.

Caferoğlu, A. (2015), Eski Uygur Türkçesi Sözlüğü. Ankara: Türk Dil Kurumu.

Clauson, S. G. (1972). An Etymological Dictionary of Pre-Thirteenth Century Turkish. Oxford: Oxford University Press.

Çelik, E. (2008). Mezîd-zâde Ayıntabî Nazmü'l-Ferâid Metin Sözlük İndeks Trpkıbasım. Yayınlanmamış Yüksek Lisans Tezi. Adnan Menderes Üniversitesi Sosyal Bilimler Enstitüsü. Aydin.

Çelik, E. (2019). Rodosî-zâde'nin Acâibü'l-Mahlûkât tercümesi [İnceleme metin sözlük tıpkıbasım]. Yayınlanmamış Doktora Tezi. Uşak Üniversitesi Sosyal Bilimler Enstitüsü. Uşak.

Dilçin, C. (1983). Yeni Tarama Sözlüğü. Ankara: TDK.

Dilçin, C. (1991). (1991). Süheyl ü Nev-bahâr (İnceleme-Metin-Sözlük). Ankara: AKM.

Doğan, C. (2019). “Dîvânu Lugâti’t-Türk’teki Hapax Kelimelere Behcetü'l-Hadâyık'tan Tanıklar.” Yeni Türkiye. Sayl: 105, s.320-327.

Ercilasun, A. B.; Akkoyunlu, Z. (2014). Kâşgarlı Mahmut Dîvânu Lugâti’t-Türk Giriş-Metin-ÇeviriNotlar-Dizin. Ankara: TDK.

Erdal, M. (1991). Old Turkic Word Formation: A Functional Approach to the Lexicon I. Wiesbaden: Otto Harrassowitz.

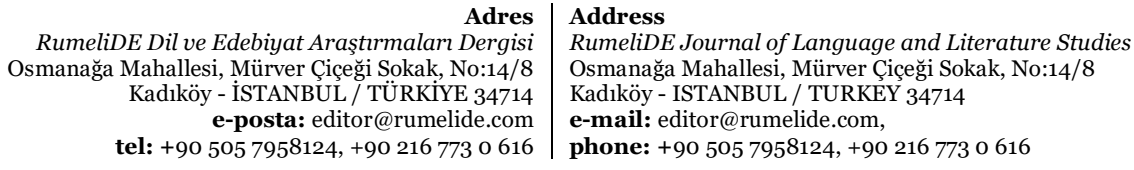


Karaca, H. (2021). Mütercimi Meçhul Bir Acayibü'l-Mahlukat ve Garayibü'l-Mevcüdat Tercümesi (İnceleme-Metin-Gramatikal Dizin-Tipkıbasım). Ankara: Grafiker.

Nur, A. (2013). "Hikâyet-i Ashâbi’l-Kehif'ten Eski Anadolu Türkçesi Söz Varlığına Katkılar.” Karadeniz Araştırmaları. Sayı: 36, 149-162.

Tietze, A. (1993). “Tarama Sözlüğü.” Türk Dilleri Araştırmaları. 267-270.

Tietze, A. (2018). Tarihî ve Etimolojik Türkiye Türkçesi Sözlüğü. Ankara: TÜBA.

Tietze, A.; Tekin, T. (1989). “Tarama Sözlüğü Üzerine Bazı Açılamalar”. Erdem. 5 (13): 285-293.

Yavuz, S. (2015). "Eski Anadolu Türkçesi Söz Varlığına Katkı-Anonim Cerrâhnâme Örneği." Turkish Studies. 10(8), 2175-2204.

Yavuz, O.; Küçükballı, F. N. (2017). "Erzurumlu Darîr'in Sîretü’n-Nebî Adlı Eserinden Eski Anadolu Türkçesinin Söz Varlığına Katkılar.” Selçuk Üniversitesi Edebiyat Fakültesi Dergisi. (38), 353380 .

Yılmaz, E.; Demir, N. (2009). "Kısas-ı Enbiyâ'dan Eski Anadolu Türkçesinin Sözvarlığına Katkılar I." International Journal of Central Asian Studies. Volum: 13, 495-517.

Yılmaz, E.; Demir, N. (2010). "Kısas-ı Enbiyâ'dan Eski Anadolu Türkçesinin Sözvarlığına Katkılar II.” Studies on the Turkic World. Festschrift in Honour of Stanislaw Stachowaki edited by E. Manczak-Wohlfeld and B. Podolak. 215-226.

Yılmaz, E.; Demir, N. (2013). "Kısas-ı Enbiyâ’dan Eski Anadolu Türkçesinin Sözvarlı̆̆ına Katkılar III.” DTCF Türkoloji Dergisi. 19(1), 159-168.

\section{Elektronik kaynaklar}

URL-1: Türk Dil Kurumu Derleme Sözlüğü https://sozluk.gov.tr/ (Erişim Tarihi:25.09.2021)

URL-2: Türk Dil Kurumu Güncel Türkçe Sözlük https://sozluk.gov.tr/ (Erişim Tarihi:25.09.2021)

URL-3: Türk Dil Kurumu Tarama Sözlüğü https://sozluk.gov.tr/ (Erişim Tarihi:25.09.2021)

RumeliDE Dil ve Edebiyat Araştırmaları Dergisi Osmanağa Mahallesi, Mürver Çiçeği Sokak, No:14/8 Kadıköy - İSTANBUL / TÜRKIYE 34714 e-posta: editor@rumelide.com tel: +90 $5057958124,+902167730616$
Address

RumeliDE Journal of Language and Literature Studies Osmanağa Mahallesi, Mürver Çiçeği Sokak, No:14/8

Kadıköy - ISTANBUL / TURKEY 34714

e-mail: editor@rumelide.com,

phone: +90 $5057958124,+902167730616$ 